\title{
Tyrosinase Inhibition from Green Tea (Camellia sinensis (L.) Kuntze) gel
}

\author{
Hanifah Rahmi ${ }^{*}$, Naniek S. Radjab ${ }^{1}$, Supandi ${ }^{1}$, Tiara Julianti ${ }^{1}$ \\ ${ }^{1}$ Department of Pharmacy, Faculty of Pharmacy and Sciences, Universitas Muhammadiyah Prof. DR. HAMKA, \\ Jakarta, Indonesia
}

Submitted 30 April 2020; Revised 15 October 2020; Accepted 22 December 2020; Published 21 June 2021

*Corresponding author: hanifah_rahmi@uhamka.ac.id

\begin{abstract}
Green tea (Camellia sinensis (L.) Kuntze) leaf has polyphenol substance that able to inhibit tyrosinase enzyme. Tyrosinase enzyme is one of the essential components that can be initiated melanin formation on the skin (melanogenesis). The natural inhibitory enzyme can be utilized in cosmetics and medicinal industries as depigmentation agent. Green tea leaf was formulated in the dosage form of a gel with carbomer 934 as a gelling agent. This study aimed to determine the optimum concentration of carbomer 934 on green tea leaf extract gel that has an inhibitory tyrosinase activity. This research used three carbomer 934 concentration, there was $0.5 \%, 0.75 \%$, and $1 \%$ respectively. Which every formula was evaluated during six weeks involve organoleptic, homogeneity, viscosity, $\mathrm{pH}$, centrifuge, and freeze-thaw test (during six cycles). The optimum formula was evaluated tyrosinase activity used a spectrophotometer-vis. The results showed that the great concentration of carbomer 934 was contained on the first formula, which has not phase separation and $49.62 \mathrm{ppm}$ of $\mathrm{IC}_{50}$ value. This research showed that green tea leaf extract gel with $0,5 \%$ carbomer 934 prevented tyrosinase activity.
\end{abstract}

Keywords: Carbomer 934, gel, green tea leaf extract, inhibitory of tyrosinase

\section{Penghambatan Tirosinase dari Gel Daun Teh (Camellia sinensis (L.) Kuntze)}

\begin{abstract}
Abstrak
Daun teh hijau (Camellia sinensis (L.) Kuntze) memiliki kandungan senyawa polifenol yang dapat menghambat enzim tirosinase. Enzim tirosinase adalah salah satu komponen yang dapat menginisiasi pembentukan melanin kulit (melanogenesis). Inhibitor tirosinase dari sumber alam dapat dimanfaatkan sebagai agen depigmentasi pada kosmetik maupun obat. Daun teh hijau dibuat dalam bentuk sediaan gel dengan carbomer 934 sebagai gelling agent. Penelitian ini bertujuan untuk menentukan konsentrasi optimum dari carbomer 934 dan mengetahui aktivitas penghambatan gel terhadap enzim tirosinase. Ekstrak daun teh hijau dibuat dalam 3 formula dengan konsentrasi carbomer 934; 0,5\% (Formula 1), $0,75 \%$ (Formula 2) dan 1\% (Formula 3). Tiap formula dievaluasi selama 6 minggu meliputi organoleptik, homogenitas, viskositas, $\mathrm{pH}$ serta uji pemisahan fase, yaitu sentrifugasi dan freeze thaw (selama 6 siklus). Formula yang optimum diuji aktivitas penghambatan enzim tirosinase menggunakan spektrofotometer UV-Vis. Hasil penelitian menunjukkan bahwa konsentrasi optimum carbomer

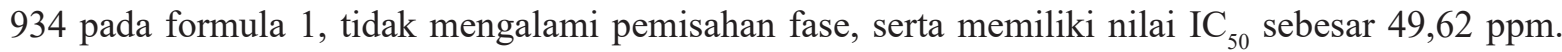
Penelitian ini menunjukkan carbomer 934 dengan konsentrasi 0,5\% pada ekstrak daun teh hijau dapat menghambat aktivitas enzim tirosinase.
\end{abstract}

Kata Kunci: Ekstrak daun teh hijau, gel, inhibitor tirosinase, karbomer 934 


\section{Introduction}

Hyperpigmentation is a disorder of facial skin pigments that is common because of an increase in the process of melanogenesis, including ultraviolet (UV) radiation, inflammation, hormones, and medications, which can cause darkening of the skin color. ${ }^{1}$ Skin darkening is a condition in which the skin produces excessive melanin, the pigment which determines skin and hair color to a varying degree. ${ }^{2}$ In addition, increasing melanin synthesis can cause local pigmentation or black spots on certain parts of the face. ${ }^{3}$ The synthesis of melanin involves tyrosinase as a critical enzyme that is catalyzing of tyrosine oxidation into dopaquinone. ${ }^{4}$ At a certain $\mathrm{pH}$ level, the process runs spontaneously, converting dopaquinone into dopa and dopachrome, which will further form melanin. ${ }^{5}$ Therefore, the process of melanogenesis can be inhibited. One of the procedures is the inhibition mechanism of tyrosinase enzymes on the skin either by using natural materials or synthetic materials.

One of the natural ingredients that have the efficacy of tyrosinase inhibitors is green tea leaves (Camellia sinensis L.). The methanol extract of $50 \%$ tea leaf has an inhibition activity of tyrosinase enzyme with an IC50 value of $51,95 \mu \mathrm{g} / \mathrm{ml}^{6}{ }^{6}$ Fresh green tea leaves contain a precious component of polyphenol derivatives is around 10-30\%, known as catechins. ${ }^{7}$ The main components of polyphenol from catechins derivatives can maximally inhibit the activity of tyrosinase that plays a role in the creation of skin pigmentation. ${ }^{8}$

Green tea leaf extract should be made in a particular physical form in a way to facilitate consumer's practicality as well as to extend the shelf life. The physical form widely used in the market is in the form of a cream. However, this form has a drawback of its instability, such as creaming or phase inversion. Referring to the relevant research, the best physical stability of a semisolid is in the form of gels, compared to other forms such as creams and ointments. ${ }^{9}$ Significantly too, gels have the advantage of having an attractive physical appearance since it is clear and colorless, ${ }^{10}$ and it is also comfortable to use because it is not fatty, which causes excessive oil on the face. Thitimuta, et al. had determined the half-inhibition concentration (IC50) of methanolic fresh tea leaves extract was $349 \pm 9.00 \mu \mathrm{g} / \mathrm{mL} .^{11}$

Carbomer or acrylic acid polymer is a gelling agent in a polymeric form that is derived from a synthetic material. ${ }^{12}$ The excessed carbomer, compared to another gelling agent, has high stability and compatibility as well as low toxicity. ${ }^{13}$ There are several types of carbomers, such as carbomer 934, 940, 941, 971, and so on. ${ }^{12}$ Carbomer 934 has good properties in the release of active substances compared with other gelling agents. ${ }^{13}$ Carbomer 934 can be used as a single-form gelling agent at a concentration of $0.5-2 \%{ }^{12}$ The optimization of carbomer 934 concentration as a gelling agent in every gel preparation is pivotal to be done for the sake of identifying the optimum value of carbomer 934, which further generates a good gel physical stability parameters.

\section{Methods}

\subsection{Instruments}

The tools used are analytical scales (Ohaus), reflux apparatus, heating mantle, vacuum rotary evaporator (Eyela), oven (Memmert), $\mathrm{pH}$ meter (La Motte $\mathrm{pH} 5$ Plus), viscometer using DVE-RVT type (Brookfield), centrifugator (K-Gemco), UV-Vis type UV-1601 spectrophotometer (Shimadzu), microscope (Yazumi), vortex mixer (K-Gemco), hotplate (Akebono), and glassware (Pyrex).

\subsection{Materials}

Dried green tea leaf powder obtained from the Indonesian Spice and MedicinalCrops Research Institute (ISMCRI), 50\% methanol, carbomer 934 (Shree Chemicals), methyl parabens, propyl parabens, propylyclicol (Dow Chemical), triethanolamine, dimethylsulfoxide (Emsure), Folin Ciaocalteu pa (Sigma Aldrich), and aquadest. Materials to test the activity of tyrosinase inhibition are as a subject, mushroom tyrosinase (Sigma 
Aldrich), levodopa as a substrate obtained from a grant from PT. Martina Berto, Tbk.

\subsection{Procedure}

\subsubsection{Extraction of the Green Tea Leaves}

A total of 20 grams of dried green tea leaves powder was extracted by reflux using $50 \%$ methanol solvent of $400 \mathrm{~mL}$. The powder was extracted for 2 hours at the boiling temperature of the solvent, which is $78^{\circ} \mathrm{C}$. The liquid extract was being concentrated by using a vacuum rotary evaporator device with a temperature of $55^{\circ} \mathrm{C}$ based on the concentrated temperature orientation. This process was run until a viscous extract could be poured and then finally weighed. ${ }^{14}$

\subsubsection{Screening of Tanins Chemical Component}

Tanin on the extract was defined by qualitative analysis. The condensed extract was re-extracted with $80 \%$ ethanol by using an vertical cooler for 15 minutes, and then it was filtered. The obtained filtrate was evaporated over a water bath. On the remaining evaporation, hot and stirred distilled water was added. After the cold solution was centrifuged, the liquid on it was separated by decantation, and the obtained solution was used as the test solution. The test solution was added a $10 \%$ gelatin solution; as a result, a white precipitate will be developed..$^{15}$

\subsubsection{Formulation}

Green tea gel was made in 3 formulas. The formula contained carbomer 934 by $0.5 \%$, $0,75 \%$, and $1 \%$, respectively. Carbomer 934 was dispersed in $50 \%$ of distilled water until it was expanding. ${ }^{12}$ After that, a $\mathrm{pH}$ check of Carbomer 934 was performed. The dispersion was then added with triethanolamine to increase the $\mathrm{pH}$, homogeneous stirring was conducted to obtain a $\mathrm{pH}$ of 6 by using a colorimetric method (using a universal $\mathrm{pH}$ indicator), and finally, the gel base was formed. Methylparaben and propylparaben were dissolved by applying propyleneglycol. ${ }^{12}$ Dimethylsulfoxide was dissolved in hot water until it was completely dissolved ${ }^{12}$; it was subsequently added to the methylparaben and propylparaben solutions. As much as $1 \%$ of green tea leaf extract was dissolved in distilled water. The extract solution was mixed with a preservative solution and DMSO until it becomes homogeneous. The gel base was then added a bit by bit into the mixture until it becomes homogeneous. The remaining distilled water was added to the gel and stirred. The obtained gel was stored in a sealed container.

\subsubsection{Evaluation of Physical Stability}

Testing was done weekly for six weeks. Organoleptic examination of the gel observes a phase separation/syneresis (if any), color and clarity, and the odor it possesses. A homogeneity test of $0.5 \mathrm{~g}$ of the gel was placed between two glass objects, and then the presence of particles or inhomogeneity was observed under the light. The $\mathrm{pH}$ measurement of acidity $(\mathrm{pH})$ was measured using a $\mathrm{pH}$ meter by dipping the electrode into a sample of green tea leaf extract gel. The $\mathrm{pH}$ value that appears on the tool screen was recorded. This measurement was made at room temperature.

The measurement of viscosity and flow properties was performed at speeds of $0.5,1$, $2,4,10,20$, and 30 , then repeated at speeds of $20,10,4,2,1$ and 0.5 . Record the number indicating the value of viscosity and dial reading that appears on the screen. ${ }^{16}$

The phase separation test was carried out only once during the test. Centrifugation test of 20.0 grams of each sample was inserted into a centrifugation tube, centrifuged at $3750 \mathrm{rpm}$ for $5 \times 60 \mathrm{~min}$, and then observed whether phase separation occurred. ${ }^{17}$ The phase separation cycle with the freeze-thaw method was carried out at six cycles for each formula. Each cycle was observed after 48 hours of storage at $4^{\circ} \mathrm{C}$ and 48 hours after at $45^{\circ} \mathrm{C}$ for 24 days.

\subsubsection{Inhibition Activity Test of Tyrosinase}

Green tea leaf extract gel was weighed and dissolved with methanol 50\%. The sample solution was made by the concentration of 25 , $50,75,100,125,150 \mathrm{ppm}$. This concentration was obtained from orientation. Tyrosinase 
enzyme for inhibition activity test was purchased from Sigma-Aldrich and levodopa obtained from PT. Martina Berto.

Subsequently, read the absorption value (absorbance) by using UV-Vis spectrophotometerat the specified wavelength, which is $481.1 \mathrm{~nm}$. The measured absorbance is the absorption of dopachrome formation. ${ }^{18}$ With the value of the obtained absorbance, calculate the percentage of the inhibition by using the formula of:

$\%$ Inhibition $=\frac{(\text { Abs Normal Control }- \text { Abs Blank })-\text { Abs Sample }}{(\text { Abs Normal Control }- \text { Abs Blank })} \times 100 \%$

The inhibition activity of the test sample was determined by the $\mathrm{IC}_{50}$ values calculated by using the linear regression equation.

\subsubsection{Data Analysis}

The absorbance value of the inhibition activity of tyrosinase was analyzed using a linear regression equation to determine the $\mathrm{IC}_{50}$ value.

\section{Results}

The obtained extract of green tea leaves had organoleptic characteristics that were viscous, blackish brown, aromatic smell of tea, and bitter taste. The yield of the extract was $53.76 \%$. The obtained results of the organoleptic tests of each formula every week, from week 0 to week 6 , had the same character that is the dark brown and obvious aromatic smell of tea. The shape of each formula had a different shape of consistency. That was, the consistency of the form is slightly thick in formula 1, quite thick in the formula 2 , and very viscous stable in the formula 3 until week 6 . Having said that, the gel is organoleptically stable enough. The results of the homogeneity test were evenly colored, and no coarse or fine particles that do not coalesce in the gel. Accordingly, the gel had good homogeneity.

The $\mathrm{pH}$ test results from all the three formulas were in the range of 4.5-6.5 for six weeks period (Figure 1). There was a decreasing viscosity of the gel in the viscosity test (Figure 2). Statistical analysis shows that the viscosity was not affected by the time variable, but it was influenced by carbomer 934 concentration. The higher carbomer 934 concentration had greater viscosity with $\mathrm{p}<0.05$. In addition to the viscosity testing, the type of fluid properties was also examined. Formula 1 and 2 were discovered to had a plastic-type of flow properties and a quite stable thixotropy, starting from week 0 to week 6 . Whereas, formula 3 had a viscoelastic type of flow properties. Centrifugation test was carried out at a speed of $3750 \mathrm{rpm}$ for 5 x 60 minutes. The result of the centrifugation testing shows that the whole formula did not experience phase separation.

The results of freeze-thaw test show that the entire gel cycle did not experience any phase separation in formula 1 . In contrast

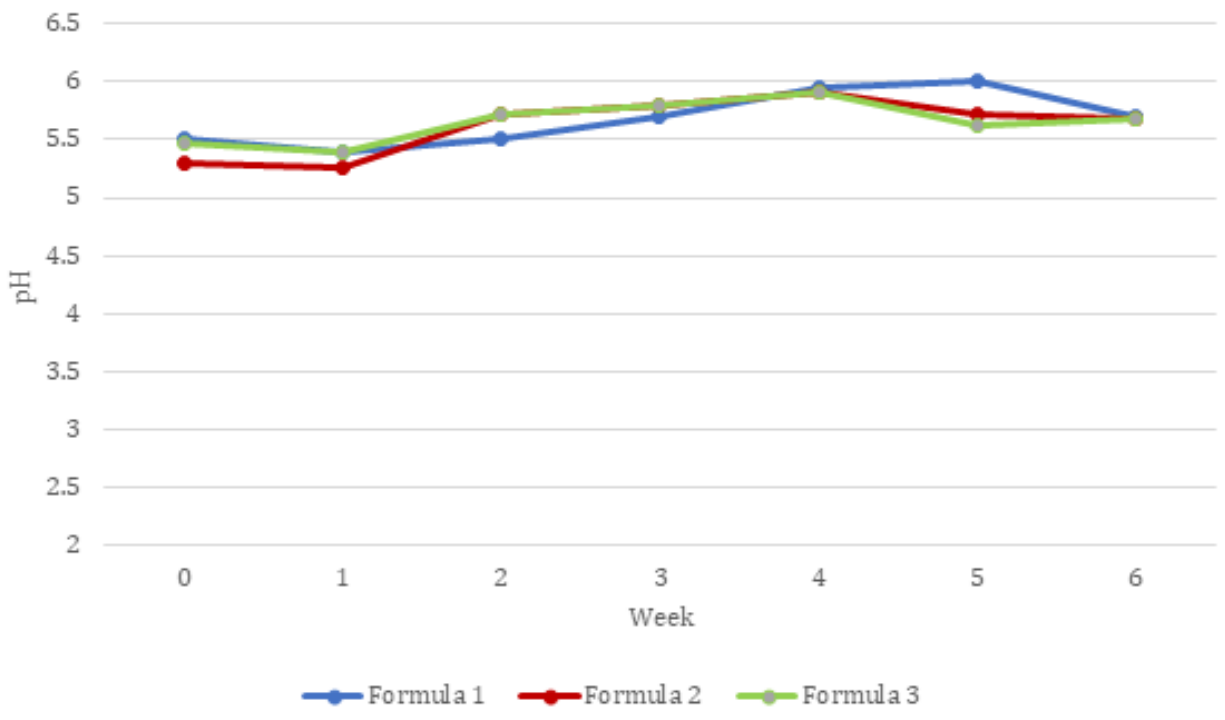

Figure 1. pH Testing Result 
to formulas 2 and 3, which experience phase change or phase separation in the sixth cycle. Formula 1 was selected to proceed with the tyrosinase inhibition test based on the overall evaluation of its physical stability. The obtained value of $\mathrm{IC}_{50}$ from formula 1 was $49.62 \mathrm{ppm}$. The $\mathrm{IC}_{50}$ values indicated that the green tea leaf extract gel played a role as a tyrosinase inhibitor. These results indicated that it had greater effectiveness in inhibiting tyrosinase enzyme compared to the positive control of the extract. This occurs because the gel base could inhibit the works of the tyrosinase enzyme even though the percentage was low (See Figure 3).

\section{Discussion}

Referring to the literature; the obtained extract of green tea leaves had the same characteristics with Farmakope Herbal Indonesia, which are concentrated extract, blackish-brown, and bitter taste on the tongue. ${ }^{19}$ The yield was in line with the requirement of tea leaf extract yield that was not less than $7.8 \%{ }^{19}$ A visual test for homogeneity of the gel was in accordance with the literature. This assessment is useful to ensure no separation of phases, no synersis (extrusion of water from a gel), and no foreign matter. $^{20}$

The $\mathrm{pH}$ values of all the formulations were in the range of 4.5-6.5, which is considered acceptable to avoid the risk of irritation upon application to the skin. This result is in line with Anwar E (2012), the gel could be used without reducing the comfortable feeling during its application, and it elevates the absorption rate of the skin. ${ }^{21}$ The viscosity result showed that the higher carbomer obtained the greater viscosity. The high viscosity has a better ability to impart the consistency to semisolid preparations. Viscosity may impact skin retention of the dosage form and drug delivery or penetration via the skin. ${ }^{20}$

Centrifugation and freeze-thaw test is useful to observe the phase separation of the gel. The centrifugation test did not predict the shelf life, but it only compared the stability of the three formulas. This result indicates the whole formula was stable enough by the centrifugal force. The freeze-thaw result indicates that formula 1 was the most stable formula for temperature, and it had a longer shelf life than any other formula. Some studies argued that the results of freeze-thaw testing for six cycles able to predict the physical stability of shelf life. ${ }^{22}$ Therefore, formula 1 can be concluded that the formula is the most stable and is predicted to has a longer shelf life than another formula. Moreover, phase separation of the gel product is one possible reason for a high variation of assay results from content uniformity test. ${ }^{20}$

The $\mathrm{IC}_{50}$ formula 1 from this research

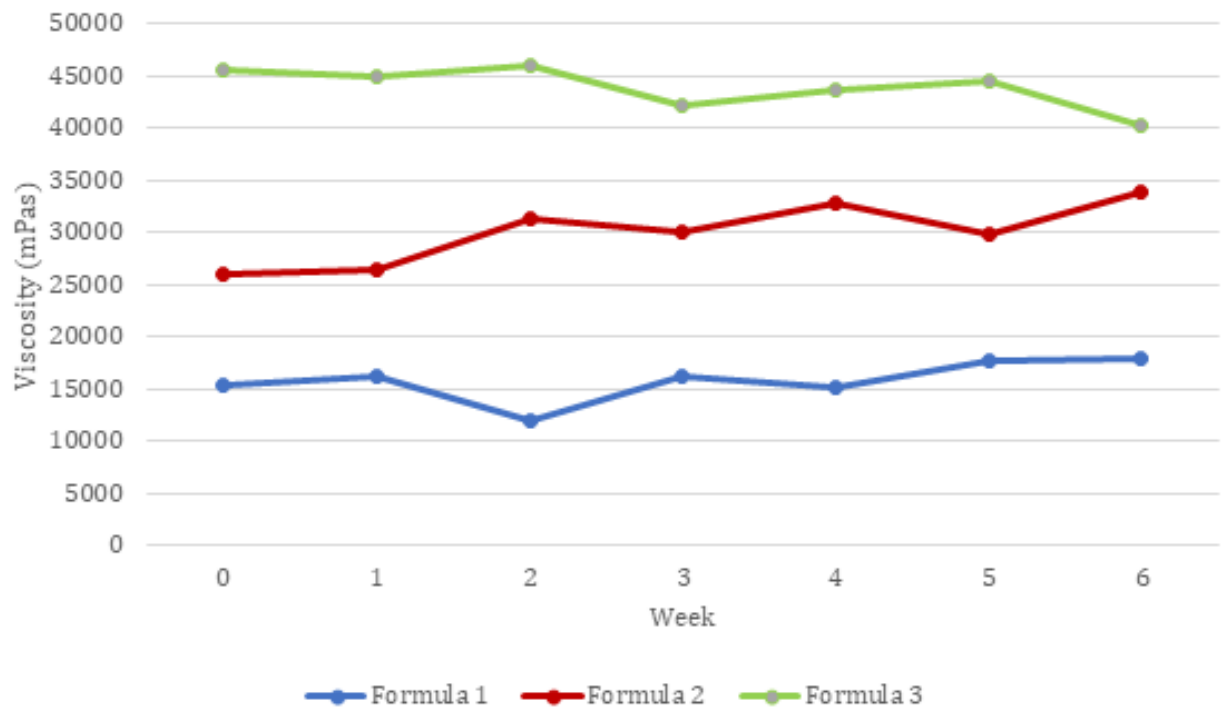

Figure 2. Viscosity Test 


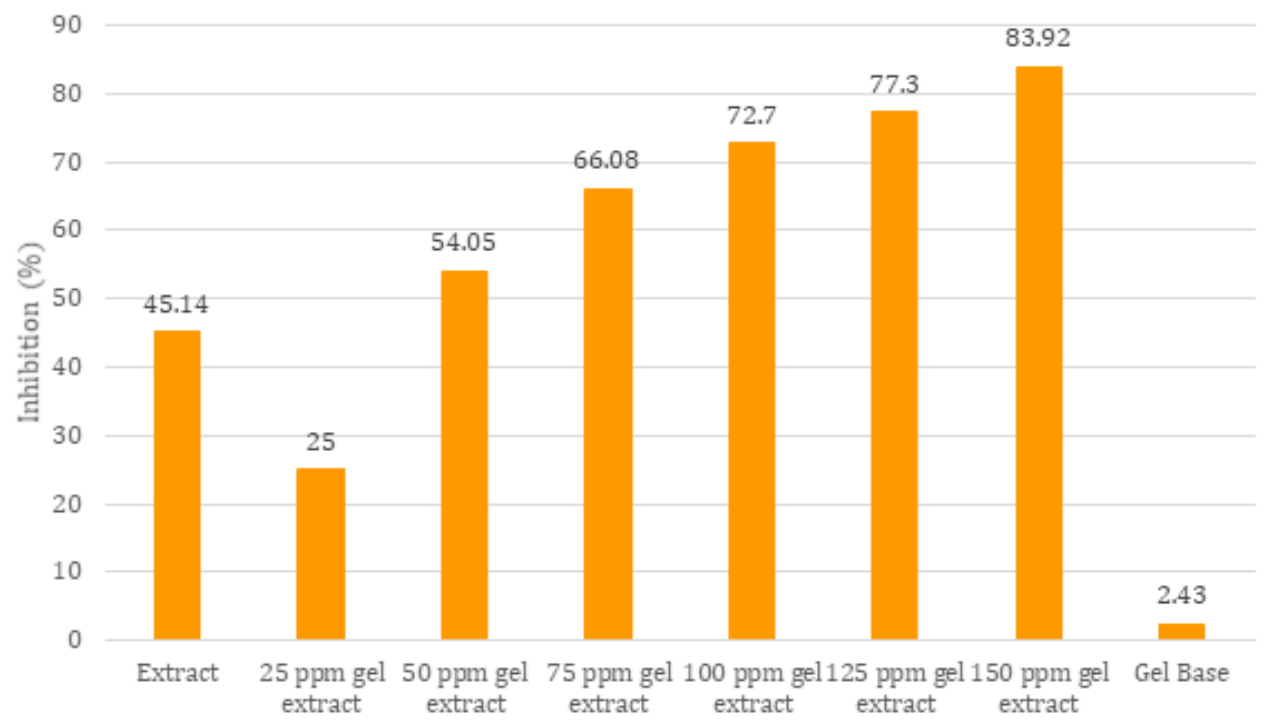

Figure 3. Tyrosinase inhibition value from variation extract concentration

was $49.62 \mathrm{ppm}$. The $\mathrm{IC}_{50}$ value of formula 1 is more effective inhibitory than $\mathrm{IC}_{50}$ extract tea leaves $(349 \pm 9.00 \mathrm{ppm})$, which is obtained in the previous study by Thitimuta $\mathrm{S}$, et al. ${ }^{11}$ Green tea is well known as a source of plant polyphenols which able to exhibit antimelanogenic effect as tyrosinase inhibitor. $^{23}$ The results show that the combination of green tea leaf extract with Carbomer 934 had an additive effect on the inhibitory ability of tyrosinase activity, which its reaction mechanism could not yet be explained.

\section{Conclusion}

Carbomer 934, as a gelling agent of green tea leaf gel, had good physical stability. Formula 1 had optimum inhibition of the mushroom tyrosinase enzyme, which is better than kojic acid $\left(\mathrm{IC}_{50}=49.62 \mathrm{ppm}\right.$ and $\mathrm{IC}_{50}=61.38 \mathrm{ppm}$, respectively). Therefore, green tea leaves gel has good potency to treat hyperpigmentation disorders because able to prevent melanogenesis by reducing the tyrosinase enzyme activity and can be a natural whitening cosmetic candidate. Carbomer 934, as a gelling agent of green tea leaf gel, had good physical stability. Formula 1 had optimum inhibition of the mushroom tyrosinase enzyme, which is better than kojic acid $\left(\mathrm{IC}_{50}=49.62 \mathrm{ppm}\right.$ and $\mathrm{IC}_{50}=61.38 \mathrm{ppm}$, respectively). Therefore, green tea leaves gel has good potency to treat hyperpigmentation disorders because able to prevent melanogenesis by reducing the tyrosinase enzyme activity and can be a natural whitening cosmetic candidate.

\section{References}

1. Reddy SB, Vashi NA. Hyperpigmentation, Edited by: Dimitris Rigopoulos, Alexander C. Katoulis. Boca Raton: CRC Press; 2017.

2. Cayce KA, McMichael AJ, Feldman SR. Hyperpigmentation: an overview of the common afflictions. Dermatol Nurs. 2004; 16(5): 401-416.

3. Criton M, Le Mellay-Hamon V. Dimeric Cinnamoylamide Derivatives as Inhibitors of Melanogenesis. Biol. Pharm. Bull. 2011; 34(3): 420-425.

4. Alam MB, Bajpai VK, Lee J, Zhao P, Byeon JH, Ra JS, Majumder R, Lee JS, Yoon JI, Rather IA, Park YH, Kim K, Na $\mathrm{M}$, Lee SH. Inhibition of melanogenesis by jineol from Scolopendra subspinipes mutilans via MAP-Kinase mediated MITF downregulation and the proteasomal degradation of tyrosinase. Scientific Reports. 2017; 7: 47858.

5. Abdel-Naser MB, Krueger-Krasagakis S, and Krasagakis K. Hyperpigmentation, Edited by: Dimitris Rigopoulos, Alexander C. Katoulis. Boca Raton : 
CRC Press; 2017.

6. Sangsrichan S, Ting R. Antioxidation and Radical Scavenging Activities and Tyrosinase Inhibition of Fresh Tea Leaves, Camellia sinensis. Science Journal Ubon Ratchathani University. 2010; 1: 76-81.

7. Yashin A, Nemzer B, Combet E, Yashin Y. Determination of the Chemical Composition of Tea by Chromatographic Methods: A Review. Journal of Food Research. 2015; 4(3): 56-87.

8. Suhandi S, Jafar G. Kajian Pustaka Hidrogel Ekstrak Daun Teh Hijau (Camellia sinensis L.) sebagai Bleaching Skin pada Mata Panda (karya tulis ilmiah). Sekolah Tinggi Farmasi Bandung, Bandung; 2014.

9. Wardiyah S. Perbandingan Sifat Fisik Gel, Krim, dan Salep yang Mengandung Etil P-Metoksisinamat dari Ekstrak Rimpang Kencur (Kaempferia galanga L.) (skripsi). Jakarta: UIN Syarif Hidayatullah; 2015.

10. Langley CA, Dawn B. Pharmaceutical Compounding and Dispensing. Second Edition. UK: Pharmaceutical Press; 2012.

11. Thitimuta S,PithayanukulP, Nithitanakool S, Bavovada R, Leanpolchareanchai J, and Saparpakorn P. Camellia sinensis L. Extract and Its Potential Beneficial Effects in Antioxidant, Anti-Inflammatory, Anti-Hepatotoxic, and Anti-Tyrosinase Activities. Molecules. 2017; 22(401): $1-14$.

12. Rowe RC, Paul JS, Marian EQ. Handbook of Pharmaceutical Excipient (6th Ed). UK: Royal Pharmaceutical Society; 2009.

13. Madan J, Singh, R. Formulation and Evaluation of Aloe Vera Topical Gels. International Journal of Pharmaceutical Science. 2010; 2(2): 515-551.

14. Rahmi H, Ramadhan R, Radjab NS. Pengaruh Konsentrasi Natrium Alginat Terhadap Gel Ekstrak Daun Teh Hijau (Camellia Sinensis L.) Sebagai Inhibitor
Tirosinase. PHARMACY. 2017; 14(2): 162-72.

15. Hanani E. Analisis Fitokimia. Jakarta: EGC; 2014.

16. Sharma B, Singh LR. Pharmaceutical gels for topical drug delivery: An overview. International Journal of Research in Pharmacy and Pharmaceutical Sciences. 2018; 3(2): 19-24.

17. Gupta PC. Physicists in Pharmaceutical Industry. PharmaTutor. 2014; 2(11): 75 76.

18. Mahardika H. Uji Penghambatan Tirosinase secara In Vitro serta Stabilitas Fisik dan Stabilitas Kimia Sediaan Krim yang Mengandung Asam Azelat (skripsi). Depok: Universitas Indonesia; 2012.

19. Indonesia Ministry of Health. Suplemen II Farmakope Herbal Indonesia. 1st Edition. Jakarta: Indonesia Ministry of Health; 2011.

20. Chang RK, Raw A, Lionberger R, Yu L. Generic Development of Topical Dermatologic Products: Formulation Development, Process Development, and Testing of Topical Dermatologic Products. AAPS Journal. 2013; 15(1): 4152.

21. Anwar E. Eksipien dalam Sediaan Farmasi: Karakterisasi dan Aplikasi. Jakarta: Dian Rakyat; 2012.

22. Bagci N, Bayindir ZS, Inal O, Altanlar $\mathrm{N}$, Yuksel N. Development and In vitro Evaluation of Nifedipine Gel Formulations for Anorectal Applications. Current Drug Delivery. 2020; 17(2): 126 $-139$.

23. Hong YH, Jung EY, Noh DO, Suh HJ. Physiological effects of formulation containing tannase-converted green tea extract on skin care: physical stability, collagenase, elastase, and tyrosinase activities. Integrative Medicine Research. 2014; 3: 25-33. 